\title{
看護専門学校教員の職務満足度
}

\author{
○嶋㟝和代 ${ }^{1} \cdot$ 椿田貴史 $^{2}$ \\ ( ${ }^{1}$ 中部大学生命健康科学部保健看護学科・2名古屋商科大学コミュニケーション学部) \\ キーワード : 看護専門学校教員・職務満足度・確認的因子分析
}

Job Satisfaction in Nursing School Teachers

Kazuyo SHIMAZAKI ${ }^{1}$, Takashi TSUBAKITA²

( ${ }^{1}$ Department of Nursing, College of Life and Health Sciences, Chubu University,

${ }^{2}$ Department of Communication, Nagoya University of Commerce and Business )

Key Words: Nursing School Teachers, Job Satisfaction, Confirmatory Factor Analysis

目 的

日本では、文部省管轄の看護大学と厚生労働省管轄の看護 専門学校という異なる養成機関において看護師教育がなされ ている。看護専門学校の多くは、小規模少人数で運営されて おり一人の教員が抱える業務量が多く、教員の負担が大きい。 看護師以上にバーンアウトや離職が多く、ベテラン教員の定 着率が低くなっており、看護教育の質の低下が危惧されてい る。専門学校の教員の就労継続を困難にしている要因は、学 生の質の変化だけでなく、業務内容や職場環境などにあるこ とも指摘されている。これまで看護師の職務満足度について は多くの研究がなされてきたが、看護教員の職務満足度に関 する研究は見当たらず、その現状は明らかになっていない。

そこで本研究では、看護婦職務満足度尺度(尾崎, 1988)に基 ら゙いて、看護教員用職務満足度尺度の作成を試みた。尾崎の 職務満足度尺度は【1. 給料】【2. 職業的地位】【3.専門職とし ての自律】【4.看護管理】【5.看護婦間相互の影響】【6.看護業 務】【7.医師と看護婦との関係】の 7 因子 48 項目から構成さ れる 6 段階リッカート尺度である。ここから【7.医師と看護 婦との関係】を省き、さらに「看護婦」を「看護教員」に、

「病院」を「学校」に置き換え、重複する内容を除いた 6 因 子 30 項目の尺度を作成した。この 6 因子構造の妥当性を検 討するために確認的因子分析を行った。

\section{方 法}

対象

$\mathrm{A}$ 地方の看護専門学校 59 校に所属する看護教員 613 名。 回収された 396 部(回収率 64.6\%)のうち、303 部(有効回答率 $76.5 \%$; 男性 13 名 -女性 322 名、年齢 30 代 73 名、40 代 152 名、50 代以上 78 名; 教員経験年数平均 10.4 年 [SD7.35〕) を分析対象とした。

\section{調查内容}

(1)フェイスシート：対象の属性を問う 28 項目

(2)看護教員用職務満足度尺度 30 項目

項目例.【2.職業的地位】「私がしている仕事を、他の人 に誇りをもって話せる」、6.業務】「この学校は、教員を含 め雇用者の福利厚生についてよく考えてくれている」、【5. 教員間の相互影響】「教員の間では、チームワークと協力 がよくできている」、など。これらについて「全くそうで ある」から「全くそうでない」の 6 段階で回答を求めた。 分析方法

記述統計結果の確認の後、看護教員用職務満足度尺度の確 認的因子分析を行った。帰無モデル、一因子モデル、6 因子 モデルの適合度を最尤法によって推定した。

\section{結 果}

各因子の平均得点は Cronbach's a 係数は.68〜.86 であった が、【業務】のみ. 38 と低い值を示した。
因子構造の妥当性については、6 因子構造モデルの方が、因 子構造を想定しない帰無モデルおよび一因子モデルよりも適 合度が高かった $\left(\chi^{2}=679.3, \mathrm{df}=390, \mathrm{CFI}=.73, \mathrm{AIC}=829.3\right.$, RMSEA=.091)ものの、Hu \& Bentler の基準を満たさなかっ た。そこで【業務】因子を削除し、AMOS の示す修正指標を 手掛かりに 5 項目の䛊差変数間に新たなパスを加え、修正 5 因子モデルを採用した $\left(\chi^{2}=493.8, \mathrm{df}=311, \mathrm{CFI}=.81\right.$, $\mathrm{AIC}=627.8$, RMSEA=.081)。

table.1

\begin{tabular}{|c|c|c|c|c|c|c|}
\hline & 1 & 2 & 3 & 4 & 5 & 6 \\
\hline $\begin{array}{c}\text { Mean } \\
\text { (SD) }\end{array}$ & $\begin{array}{r}9.53 \\
-(4.72) \\
\end{array}$ & $\begin{array}{l}27.64 \\
(5.85) \\
\end{array}$ & $\begin{array}{l}12.46 \\
(4.35) \\
\end{array}$ & $\begin{array}{r}25.69 \\
(7.03) \\
\end{array}$ & $\begin{array}{l}14.32 \\
(4.95) \\
\end{array}$ & $\begin{array}{r}6.25 \\
(2.73) \\
\end{array}$ \\
\hline 1 給料 & 1 & & & & & \\
\hline 2 職業的地位 & $.236^{* *}$ & 1 & & & & \\
\hline 3 自律 & $.298^{* *}$ & $.591^{* *}$ & 1 & & & \\
\hline 4 管理 & $.427^{* *}$ & $.596^{* *}$ & $.701^{* *}$ & 1 & & \\
\hline 5 相互影響 & $.126^{*}$ & $.531^{* *}$ & $.517^{* * *}$ & $.523^{* *}$ & 1 & \\
\hline 6 業務 & $.244^{* * *}$ & $.194^{* *}$ & $.337^{* * *}$ & $.396^{* *}$ & $.319^{* *}$ & 1 \\
\hline Cronbach's a & .78 & .76 & .68 & .79 & .86 & .38 \\
\hline
\end{tabular}

Note. SD stands for standard deviation. ${ }^{*} p<.05, * * p<.01$.

\section{考 察}

尺度全体の平均得点率は看護師に比べてやや高く、一般的 な社会人同様に、年齢・経験年数とともに満足感が高くなって おり、特に【職業的地位】【管理】では満足度が高かった。専 門学校の教員は自己の職業に誇りをもつているにもかかわら ず、就労継続が困難となっている要因は業務内容や職場環境に あることが推測される。【業務】の Cronbach's a 係数が極端に 低かったこと、確認的因子分析の結果、これを除いた修正 5 因 子モデルが最も適合度が高かったことから、本尺度における 【業務】に関する質問項目が、看護教員の業務内容の満足度を 評価する項目としては妥当でなかったことが考えられる。本尺 度の質問項目は看護師が病院で行う業務を学校に置き換えた ものであったが、患者を対象とする臨床現場での業務と、学生 を対象とする教育現場での業務には大きな差異があることか ら、今後は看護教員の業務内容を反映させた質問項目を検討す る必要がある。

\section{引用文献}

Stamps, P.L., Piedmont, R.B., Slavitt, E.B., \& Hasse, A.M. (1978). Measurement of work satisfaction among health professionals. Medical Care,16 (4),337-352.

尾崎フサ子 - 忠政敏子(1988) 看護婦の職務満足度質問紙の 研究. 大阪府立大学看護短期大紀要, vol.3(1), 17-24 